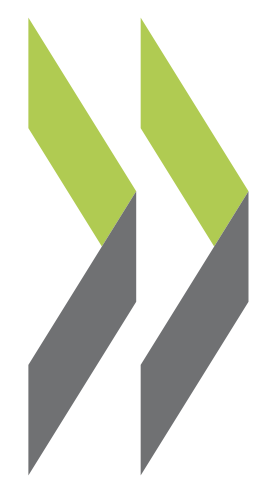

OECD Working Papers on Insurance and Private Pensions No. 41

Policy Action in Private Occupational Pensions in Japan since the Economic Crisis of the 1990s

\section{Ministry of Health, Labour and Welfare, Japan,}

\author{
Junichi Sakamoto
}




\section{\ECD}

POLICY ACTION IN PRIVATE OCCUPATIONAL PENSIONS IN JAPAN SINCE THE ECONOMIC CRISIS OF THE 1990s

by

Ministry of Health, Labour and Welfare, Japan

Mr. Junichi SAKAMOTO, Nomura Research Institute

February 2010

OECD WORKING PAPER ON INSURANCE AND PRIVATE PENSIONS

No. 41

Financial Affairs Division, Directorate for Financial and Enterprise Affairs Organisation for Economic Co-operation and Development

2 Rue André Pascal, Paris 75116, France

www.oecd.org/daf/fin/wp 


\section{ABSTRACT/RÉSUMÉ \\ Policy Action in Private Occupational Pensions in Japan since the Economic Crisis of the 1990s}

The public pension system of Japan provides coverage for all, irrespective of occupation and income. Corporate pension plans provide additional benefits over the public pension in order to meet the diversified financial needs in retirement and play a key role in enriching people's life after retirement.

The majority of corporate pensions in Japan are defined-benefit type. Consequently, a great amount of attention is paid to benefit rights. Nevertheless, in order to avoid the discontinuation of pension plans due to over-emphasis on benefit rights, Japan introduced a measure under the stagnant economy during the 1990s allowing pension plans to reduce accrued benefits under certain strict conditions, only when the government acknowledges that the sponsoring company will go bankrupt if employers are forced to continue to contribute to the pension plans to the same extent. At the same time, Japan introduced another measure allowing pension plans to use smoothing for valuing its assets in order to avoid temporary market fluctuations. As a result, corporate pension plans in Japan became manageable from a long-term perspective and able to adopt a flexible plan design whilst still ensuring benefit rights.

JEL codes: D14, D91, E21, G11, G38, J14, J26

Key words: Tax-qualified Pension Plan system (TQPP), Employees' Pension Fund system (EPF), Definedbenefit pension, Defined-contribution pension

$* * * * *$

\section{L'intervention des pouvoirs publics dans les régimes privés de retraite professionnels au Japon depuis la crise économique des années 90}

Le système public de retraite du Japon couvre tous les individus, indépendamment de leur situation professionnelle et de leurs revenus. Les régimes de retraite d'entreprise offrent des prestations complémentaires, qui s'ajoutent à la pension publique et permettent de satisfaire des besoins financiers diversifiés à la retraite, et contribuent de manière essentielle à améliorer la qualité de vie des individus après leur départ en retraite.

La majorité des régimes de retraite d'entreprise sont des dispositifs à prestations définies au Japon. En conséquence, une grande attention est accordée aux droits à prestations. Néanmoins, afin d'éviter qu'une focalisation excessive sur ces droits à prestations ne débouche sur la liquidation de certains régimes de retraite, le Japon a adopté pendant la période de stagnation économique des années 90 des dispositions permettant aux régimes de retraite de réduire les droits constitués sous des conditions strictes, uniquement si le gouvernement reconnaît que l'entreprise promoteur du régime fera faillite si l'employeur est contraint de continuer à financer le régime considéré dans les mêmes proportions. Parallèlement, le Japon a adopté d'autres dispositions permettant aux régimes de retraite d'utiliser une méthode de lissage pour l'évaluation de leurs actifs, afin d'éviter des variations liées aux fluctuations temporaires des cours du marché. En conséquence, les régimes de retraite d'entreprise du Japon sont devenus gérables dans une perspective à long terme, et ont pu adopter une structure souple tout en préservant les droits à prestations.

Codes JEL : D14, D91, E21, G11, G38, J14, J26

Mots clés : plan de retraite défiscalisé (PRD), fonds de pension des salariés (FPS), régime de retraite à prestations définies, régime de retraite à cotisations définies 


\section{Copyright OECD, 2010}

Applications for permission to reproduce or translate all, or part of, this material should be made to: Head of Publications Service, OECD, 2 rue André-Pascal, 75775 Paris Cédex 16, France. 


\title{
POLICY ACTION IN PRIVATE OCCUPATIONAL PENSIONS IN JAPAN SINCE THE ECONOMIC CRISIS OF THE 1990S
}

\author{
By The Ministry of Health, Labour and Welfare of Japan and Junichi Sakamoto ${ }^{1}$
}

\section{Policy actions during the economic crisis of the $1990 \mathrm{~s}$}

\section{Establishment of corporate pension system}

The Japanese occupational pension system emerged after World War II from the older system of severance payments. The Tax-qualified Pension Plan system (TQPP) was introduced in 1962, as a means of levelling off the cost of severance payments from employers. In addition to this system, the Employees' Pension Fund system (EPF) was established in 1965, in order to allow for increasing Employees' Pension Insurance (EPI) benefits to an adequate level, which was a social security pension scheme for private employees and faced substantial cutbacks as a result of fierce inflation following World War II. The EPI benefit increase would have incurred additional costs for employers who had already introduced severance payment plans, therefore the government introduced the EPF system whereby EPF plans substitute a portion of the old-age EPI benefit and sponsoring employers and employees are exempted from paying the corresponding portion of the EPI contributions, and instead paying them to the EPFs. EPFs also provide additional, distinct benefit on top of the substitution portion.

TQPP is an occupational pension contract between the company which establishes the pension plan and the pension management companies, such as insurance companies or trust banks. The plan benefits from preferable tax treatment, having been approved by the Commissioner of the National Tax Agency as meeting the 14 requisite criteria in the tax code. EPF substitutes a part of the public old-age EPI benefit and provides its own additional retirement benefits on top of it. The EPF plans enjoy more favourable tax treatment than the TQPP plans in respect of, for example, the employees' contributions and the tax on the reserve funds.

These two private occupational pension systems are defined-benefit type and played a major role in providing retirement income for employees since their foundation until the end of the 1990s. However, in response to the changing corporate pension environment in the 1990s, Japan went through a corporate pension system reform in 2001 by establishing a new type of defined-benefit pension and a definedcontribution type pension, and a variety of options have since become available. This reform also enabled EPF to stop substituting public pensions by returning the corresponding fund to the national government. No new TQPP contracts have been approved since April 2002 and the existing TQPPs will be converted to another form of corporate pension by the end of March 2012. (Existing TQPPs will no longer receive favourable tax treatment after April 2012.)

\footnotetext{
${ }^{1}$ This paper was prepared by the Ministry of Health, Labour and Welfare of Japan and Junichi Sakamoto, Nomura Research Institute. The views expressed are the sole responsibility of the authors and do not reflect those of their organizations. The authors are solely responsible for any errors.
} 


\section{Outline of the economic background of the 1990's}

The environment surrounding corporate pensions in Japan underwent three changes in the 1990s: a downturn of companies' performance, changes in employment and human resource management, and a change in accounting standards.

Firstly, companies experienced a long-lasting downturn after the collapse of the economic bubble late in the 1980s followed by a financial crisis late in the 1990s. The situation made it extremely difficult for EPFs to obtain investment returns of no less than 5.5\%. Such environmental change forced the government to review the funding rules of the EPF.

Secondly, there were changes in employment and human resource management practices in Japanese companies that had important effects on pension provision. Generally speaking, Japanese companies offer lifetime employment and seniority-based salaries, and these practices were taken into account in designing severance payments and other fringe benefits, including the corporate pension plans. However, as a result of the downturn experienced by many companies, they could no longer afford to continue these practices. Following a review of these practices, it was recognised that the corporate pension system needed increased portability both in terms of the pension plan's rules and benefit design.

Thirdly, an accounting standard change resulted in the underfunding status of retirement benefit plans being partially or wholly stated on the sponsoring company's balance sheet. This change adversely affected EPFs because they had to bear the risks of under-funding resulting from managing assets corresponding to the substituting portion of the old-age EPI pension in addition to the risks additional portion as corporate benefits themselves will bring about. As a result, a new defined-benefit type corporate pension scheme that would be free from the obligation to substitute a part of social security pension, as well as a new defined-contribution type pension that would not require additional funding responsibility from employers were called for, with the aim of making corporate pension system more adaptable to the characteristics of each company. In this case the new defined-benefit type corporate pension scheme should take greater account of the benefit rights of beneficiaries and participants than the TQPP plans did.

\section{Overview of policy response to economy changes}

The Government took several steps in the face of these changes, with the aim of enabling sponsored companies to design pension plans more freely, as well as strengthening financial regulation, including funding requirements, in order to secure beneficiaries' right. A series of reforms also aimed to improve the private corporate pension system, so that it could play a supplementary role in public pensions, which were to be cut by $5 \%$ in the 2000 reform in order to contain the growth of public pension expenditure. In this context, the following sections describe the measures taken for the EPF system against the financial crises of the 1990s, as well as reforms of corporate pensions in general.

\section{Response to Employee's Pension Fund under economic crisis}

\section{Actions taken to improve the Employees' Pension Fund System}

Given the substantial assets of the EPF system, as it substitutes a part of public pensions, it has recorded a stable asset return, exceeding the assumed interest rate of return 5.5\% under the high growth economy since its establishment in 1966.

However, drastic changes to the financial and economic situation after the collapse of the bubble economy, as well as changes to the industrial structure, made it difficult to maintain a rate of return superior to the assumed interest rate, resulting in the deterioration of the funds' finances. Under these circumstances, sponsor companies found it difficult to uphold the obligation to substitute the management 
of public pension assets and consequently, there was an increase in the number of EPF funds returning the substitution portion to the public pension system, transforming them into purely DB type pension funds or terminating pension funds. This was also partly due to the change to the accounting rule of the retirement benefit whereby the sponsors should partially or wholly state the underfunding status on the balance sheet. Government analysis concluded this trend was a problem caused by inflexible regulation that does not allow pension funds to adjust to economic change, and the government and the legislators decided to reform the Employees' Pension Fund system.

Table. 1 Trend of terminated EPF plans

\begin{tabular}{|c|r|r|r|r|r|r|r|r|r|r|r|r|r|r|r|}
\hline Fiscal Year & $1966-1994$ & 95 & 96 & 97 & 98 & 99 & 00 & 01 & 02 & 03 & 04 & 05 & 06 & 07 & Total \\
\hline Total & 18 & 1 & 7 & 14 & 18 & 16 & 29 & 59 & 73 & 92 & 81 & 30 & 8 & 11 & 457 \\
\hline $\begin{array}{c}\text { Single/Affiliated } \\
\text { employer }\end{array}$ & 16 & 0 & 3 & 11 & 16 & 13 & 27 & 56 & 57 & 57 & 54 & 15 & 0 & 0 & 325 \\
\hline Multi-emloyer & 2 & 1 & 4 & 3 & 2 & 3 & 2 & 3 & 16 & 35 & 27 & 15 & 8 & 11 & 132 \\
\hline
\end{tabular}

Source: Ministry of Health, Labour and Welfare, Japan

Note: The number does not include the cases where the EPFs shifted to the contract-type DB corporate pension plans by returning the substitution portion to the government though under the law, those cases are deemed to be plan termination.

Table.2 Trend of financial situation of EPF plans

\begin{tabular}{|l|r|r|r|r|r|r|r|r|r|r|r|r|r|}
\hline & 1994 & 1995 & 1996 & 1997 & 1998 & 1999 & 2000 & 2001 & 2002 & 2003 & 2004 & 2005 & 2006 \\
\hline $\begin{array}{l}\text { Over } \\
\text { funded } \\
\text { funds }\end{array}$ & 992 & 885 & 640 & 781 & 559 & 1,505 & 159 & 96 & 87 & 467 & 426 & 639 & 609 \\
$(54 \%)$ & $(47 \%)$ & $(34 \%)$ & $(42 \%)$ & $(30 \%)$ & $(82 \%)$ & $(9 \%)$ & $(6 \%)$ & $(5 \%)$ & $(34 \%)$ & $(51 \%)$ & $(93 \%)$ & $(95 \%)$ \\
\hline $\begin{array}{l}\text { Under } \\
\text { funded } \\
\text { funds }\end{array}$ & 832 & 988 & 1,238 & 1,093 & 1,299 & 329 & 1,642 & 1,640 & 1,569 & 890 & 411 & 48 \\
$(46 \%)$ & $(53 \%)$ & $(66 \%)$ & $(58 \%)$ & $(70 \%)$ & $(18 \%)$ & $(91 \%)$ & $(94 \%)$ & $(95 \%)$ & $(66 \%)$ & $(49 \%)$ & $(7 \%)$ & $(5 \%)$ \\
\hline Total & 1,824 & 1,873 & 1,878 & 1,874 & 1,858 & 1,834 & 1,801 & 1,736 & 1,656 & 1,357 & 837 & 687 & 640 \\
\hline
\end{tabular}

\begin{tabular}{|l|l|l|l|l|l|l|l|l|l|l|l|l|}
\hline $\begin{array}{l}\text { Rate of } \\
\text { return } \\
(\%)\end{array}$ & 0.74 & 10.27 & 3.65 & 5.65 & 2.56 & 13.09 & -9.83 & -4.16 & -12.46 & 16.17 & 4.74 & 21.0 \\
\hline
\end{tabular}

Source: Ministry of Health, Labour and Welfare, Japan 


\section{Reform measures of the Employees' Pension Fund System}

1997

\section{(1) Relaxing the rule of assumed interest rates}

EPF regulations used to require all pension funds to apply the assumed interest rate of $5.5 \%$ when they decided upon contributions and calculated the actuarial liability. However, the difficult economic and financial environment that lasted throughout the 1990s made them unable to achieve the assumed interest rate from the investment. Therefore the government relaxed the regulations on the application of the assumed interest rate and allowed pension funds to set the rate within a certain range. Relaxing the investment regulation (see (7)) was another factor for the relaxation of the rule regarding the assumed interest rate.

\section{(2) Transition from book value evaluation to mark-to-market (actuarial) value evaluation}

Until the early 1990's, the EPFs invested their reserve funds mainly in domestic bonds or general accounts of life insurance companies that guaranteed a certain interest rate. As a result, the EPF reserve funds were evaluated in terms of book value or acquisition price. However, as the guaranteed interest rate of the general account of life insurance companies declined, EPFs demanded the government to allow them to invest their reserve funds in equities more freely, in the expectation of of obtaining a higher long-term return. Responding to this demand, the government relaxed the investment regulations in the late 1990's. This relaxation resulted in a decrease of investment in the general accounts of life insurance companies and in an increase of investment in equities and foreign assets. These assets are more volatile and assume greater risks and it would be unhealthy management of the EPFs if they continued to evaluate the reserve funds in terms of book value, which would not tell anything about the capital loss. Therefore the government decided to change the way of evaluating the reserve funds from the book value method to the mark-to-market method. At the same time the government allowed the EPFs to adopt smoothing since the mark-to-market evaluation quite often fluctuates for temporary reasons. At present the EPFs are allowed to adopt mark-to-market evaluation or smoothed evaluation or the lower of the two.

\section{(3) Introduction of funding requirements based on plan termination liabilities}

Previously, funding standards required actuarial valuations based solely on plan continuation liabilities, which assesses whether funding is following the original schedule on the presumption that the EPF continues to exist. Under the plan continuation concept, under-funding can be recovered by adjusting the schedule of future contributions instead of recovering the under-funding immediately. A shift in the asset portfolio to volatile assets and the increased incidence of EPF fund termination drove the introduction of plan termination evaluations with a view to securing the rights of plan beneficiaries and participants in the case of EPF fund termination. As a result, beneficiaries' security was strengthened, and sponsor companies now have to pay an additional contribution, if necessary, in cases of under-funding of plan termination evaluation.

\section{(4) Relaxing the rule against benefit adjustment}

Previously, it was prohibited to cut accrued benefit when EPF funds review benefit design. However, following several incidents of EPF fund termination due to financial and economic turbulence, the rule was changed to allow cuts in accrued benefits under the strict conditions of, firstly, unavoidable financial reasons such as sponsor companies' downturn and, secondly, the agreement of at least two thirds of members with the proposal. 


\section{(5) Introduction of the designated actuary system}

Since 1988, actuarial evaluation by actuary has been mandated for pension entities, for the sake of ensuring rights of beneficiaries and plan members. Under the liberalized financial regulations, it is vital that each EPF funds have an appropriate mechanism to monitor and adjust according to the financial situation and in a timely manner in order to ensure active financial management by each EPF fund. To this end, the designated actuary system was established. Under this system, each EPF must designate an actuary who will remain to evaluate and to advise on the financial situation.

\section{(6) The guideline on the role and responsibilities of investment officers in EPFs}

"The guideline on the role and responsibilities of investment officers in EPFs" was established in order to clarify the role and responsibilities of an investment officer in an EPF, which enables EPFs to manage and be responsible for the fund under the relaxed regulations.

\section{(7) Termination of 5:3:3:2 regulation}

The Government abolished the asset allocation regulation which had required EPFs to allocate more than $50 \%$ of the fund to a principal-guaranteed asset, less than $30 \%$ in domestic equity, less than $30 \%$ in foreign currency based assets, and less than $20 \%$ in real estate. The abolition of this legal list enabled EPFs to efficiently manage funds and to effectively cope with the financial downturn.

1999

\section{Freezing exempted contribution}

As a consequence of the freezing of the public EPI contributions under the economic slump in the 2000 pension reform, the way of calculating the exempted contributions was also frozen. In other words, the exempted contributions no longer reflected the projected actual cost of the substituted benefits. The government, therefore, also changed the way of calculating the buy-back reserve after 1 October 1999, from calculating the present value of the future substituted benefits to calculating the residual reserve fund, with exempted contributions and investment return classed as revenue and the substituted benefits as expenditures, starting with the buy-back reserve at the end of September 1999 that was calculated as the present value of the substituted benefits. The 2004 reform thawed the frozen exempted contributions, but the way of calculating the buy-back reserve remained unchanged, namely calculating the residual reserve fund. The government judged that the way of calculating the residual reserve fund is financially neutral between the EPI scheme and the EPFs, in that it gives financial advantage neither to the EPFs nor to the EPI scheme.

\section{Relaxing funding requirements}

The government, for the time being, is allowing EPFs 10 years to recover from under-funding instead of the previous limit of 7 years.

2004

\section{(1) Special treatment on plan termination}

When an EPF terminates, it must transfer buy-back reserve to the PFA. However, a reduction of the buy-back reserve or instalment payment was authorised as a temporary measure from FY 2005 to FY 2007 
if the government acknowledged that the sponsoring companies were in financial trouble preventing the immediate recovery of the under-funding of the buy-back reserve.

\section{Establishment of options other than EPF}

Under adverse economic circumstances, the substitution portion of EPF became difficult to sustain for sponsor companies. They had to make additional contributions of twice the normal size to recover underfunding. Furthermore, they had to disclose the under-funding status on financial statements under the new accounting rule. As a result, there was a rise in the number of companies who called for defined benefit type corporate pension framework without substituting the old-age EPI benefit. EPF also has disadvantages, including:

Low prevalence among small to medium enterprises

Insufficient portability of pension assets when an employee changes jobs, which might have prevented labour mobility.

In this context, two new private pension schemes were established. In 2001, Defined-Contribution pensions and Defined-Benefit type corporate pensions, without substituting the old-age EPI benefits, were introduced. The Defined Benefit Corporate Pension System has two types of pension plan: a contract-type corporate pension plan where employers have a direct contract with managing companies like trust banks and life insurance companies and a fund-type corporate pension plan where employers establish a separate fund. Employees' agreement by majority is necessary if employers want to introduce the Defined Benefit Corporate Pension Plan or the Defined Contribution Pension Plan. In relation to this, we should note at this point that cash balance plan designs started to be permitted for the additional benefit portion of the EPF plans and the DB Corporate Pension Plans in April 2002. As to the regulations applied to the DB corporate pension plans, they are almost the same as those applied to the additional benefit portion of EPF plans though there are some differences.

By introducing the Defined Benefit Corporate Pension Plan system, EPFs started to be allowed to return the substitution portion of the old-age EPI pensions to the national government. The government has stopped receiving applications for new TQPP plans since April 2002 because it does not have clear funding requirements as a rule. Existing TQPPs will have to convert to another form of corporate pension plan by the end of March 2012. (Existing TQPPs will no longer receive favourable tax treatment after April 2012)

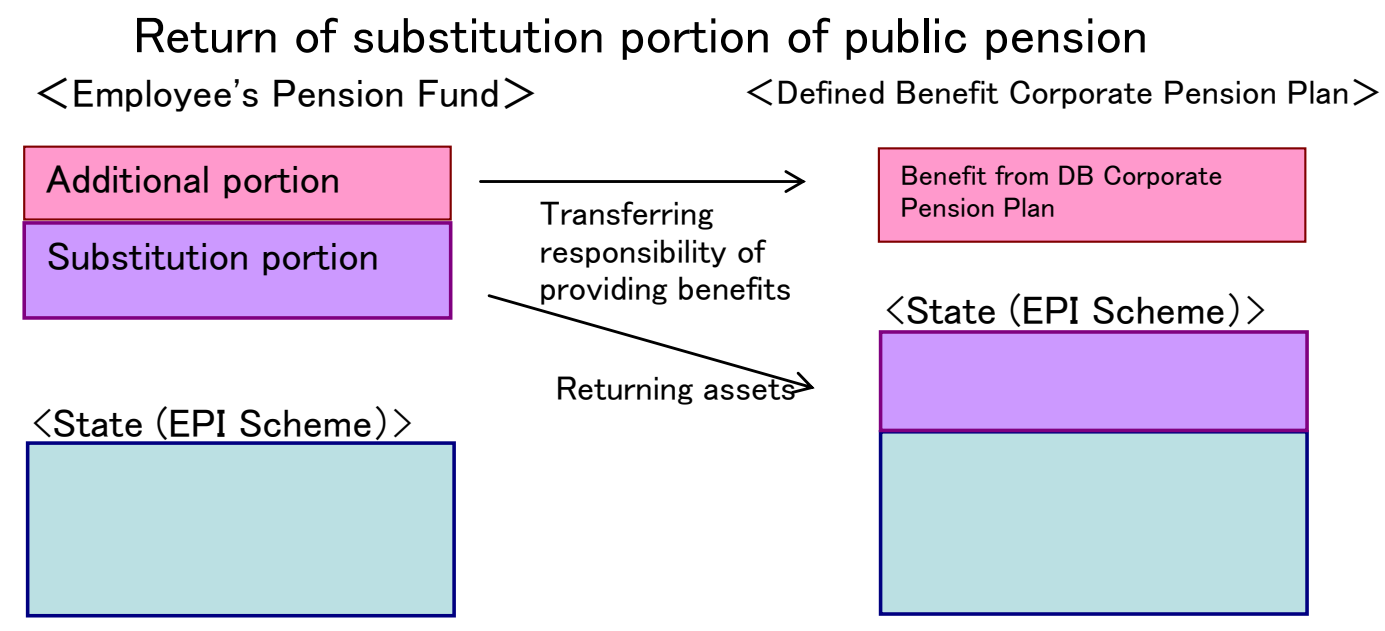




\section{Impact of the policy measures}

Policy measures taken against economic crisis in the 1990s had several consequences including, among others, a massive return of substitution portions, the revision of the assumed interest rate and changes in asset allocation by many EPFs. The following sections describe them in detail. We also describe how the Defined Benefit Corporate Pension Plan and Defined Contribution Pension Fund are growing.

\section{(1) Returning the substitution portion of the EPFs to the EPI scheme}

Even after the change in 1999 of calculating the buy-back reserve of the substitution portion as described in paragraph 18, sponsor companies had to state the under-funding status on their balance sheet in an exaggerated manner due to the accounting rule. In response to the economic downturn late in the 1990s and the beginning of this century, many EPFs returned the substitution portion in 2003, 2004 and 2005. This trend decreased in 2006 and 2007.

Table.3 Trend of returning substitution portion

\begin{tabular}{|c|c|c|c|c|c|c|}
\hline 2002 & 2003 & 2004 & 2005 & 2006 & 2007 & Total \\
\hline 0 & 203 & 438 & 121 & 21 & 20 & 803 \\
\hline
\end{tabular}

Source: Ministry of Health, Labour and Welfare, Japan

\section{(2) Revision of the assumed interest rate}

In response to the relaxing of the regulation on assumed interest rate in 1997, many of the single sponsor pension funds (pension funds established by a single company) and affiliate sponsor pension funds (pension funds established by a group of affiliated companies) decreased their assumed interest rate to more realistic level. However, some multiple sponsor pension funds (established by a group of independent companies affiliated on industrial or regional basis) have maintained a higher assumed interest rate because it is very difficult for them to obtain agreement to raise the contributions from the participating employers. There is also a tendency to keep the assumed interest rate high in order to avoid raising the contribution rates and to depend on the high return of investment under the pressure toward higher cost caused by the maturing of the industry that incurs demographic ageing within the industry. However, this strategy of seeking higher yield has resulted in a vicious cycle where pension plans face further pressure to increase contribution rates as a consequence of an unfavourable market environment. 


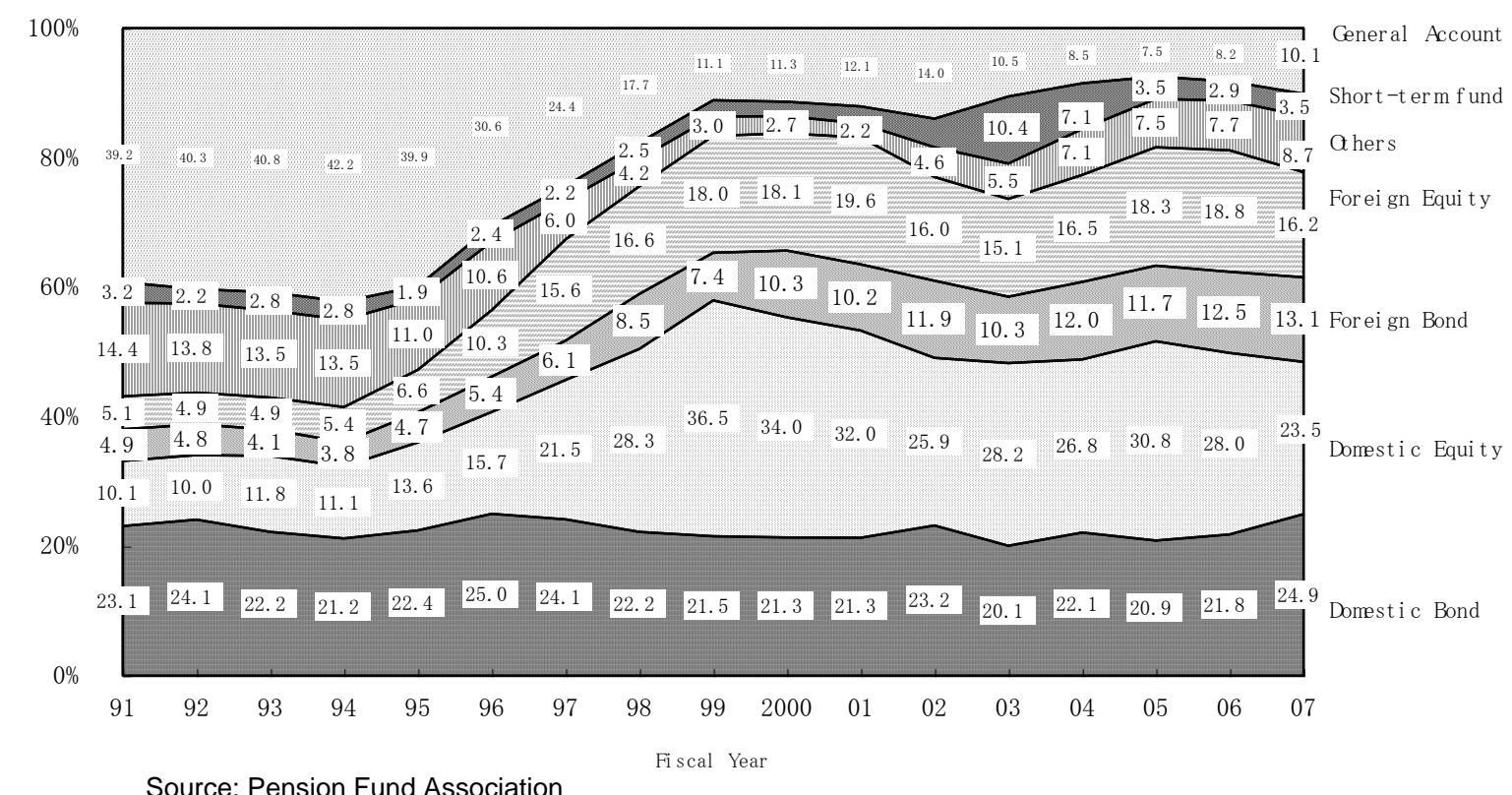

\section{(3) Change in asset allocation}

Until the mid-90s, most EPF assets were allocated in domestic bonds and general account of insurance companies which guaranteed a fixed rate of return. However, as the guaranteed rate of return by insurance general account decreased, pension funds sought high-return assets such as equity. In order to meet these needs, the government relaxed the regulation on asset management (Termination of 5:3:3:2 regulation), which lead to a decrease in the proportion of general account of insurance and an increase in domestic equity and foreign assets.

\section{(4) DB pension and DC pension system}

The number of EPFs has decreased due to the return of the substitution portion to the EPI scheme and a general winding up of the system. On the other hand, the numbers of DB corporate pension plans and DC plans have steadily increased since their inception. Most of the DB corporate pension plans were fund-type plans at the initial stage that were converted from EPF plans of large companies by returning the substitution portion to the EPI scheme, but the number of contract-type DB corporate pension plans that have been converted from TQPP plans of small and medium-sized companies are now increasing. Another characteristic of the recent move in DB corporate pension plans is that the number of DB corporate pension plans that adopt cash balance plan designs is increasing. The number of DC pension plans is also steadily increasing through conversion from TQPP plans and severance payment plans. However there has been a strong demand for the relaxation of the conditions for early leavers who are eligible for withdrawing the reserve before the retirement age in the DC pension plans. There has also been strong demand for the extension and strengthening of the portability of private pensions. The government has discussed these issues related to DC plans and has submitted two bills to the Diet for relaxing the conditions for early leavers eligible for withdrawing the reserve before retirement age and for introducing employees' contributions to DC plans. 
Table.4 Trend of EPF membership

\begin{tabular}{|c|c|c|}
\hline FY & The number of funds & $\begin{array}{c}\text { The number of membership } \\
\text { (thousand) }\end{array}$ \\
\hline 1992 & 1,687 & 11,571 \\
\hline 1993 & 1,779 & 11,919 \\
\hline 1994 & 1,824 & 12,051 \\
\hline 1995 & 1,873 & 12,130 \\
\hline 1996 & 1,878 & 12,096 \\
\hline 1997 & 1,874 & 12,254 \\
\hline 1998 & 1,858 & 12,002 \\
\hline 1999 & 1,834 & 11,692 \\
\hline 2000 & 1,801 & 11,396 \\
\hline 2001 & 1,736 & 10,871 \\
\hline 2002 & 1,656 & 10,386 \\
\hline 2003 & 1,357 & 8,351 \\
\hline 2004 & 838 & 6,152 \\
\hline 2005 & 687 & 5,310 \\
\hline 2006 & 658 & 5,221 \\
\hline Source: Ministry of Health, Labour and Welfare based on financial statement
\end{tabular}

Table.5 Trend of Defined Benefit Corporate Pension Plans

\begin{tabular}{|c|r||r|r||r|}
\hline $\begin{array}{c}\text { Fiscal Year } \\
\text { (As of the end of } \\
\text { FY) }\end{array}$ & $\begin{array}{c}\text { Number of } \\
\text { member } \\
\text { (thousand) }\end{array}$ & $\begin{array}{c}\text { Number of plan } \\
\text { (Contract-type) }\end{array}$ & $\begin{array}{c}\text { Number of plan } \\
\text { (Fund-type) }\end{array}$ & Total \\
\hline 2002 & 30 & 15 & 0 & 15 \\
\hline 2003 & 1,350 & 164 & 152 & 316 \\
\hline 2004 & 3,140 & 478 & 514 & 1,092 \\
\hline 2005 & 3,840 & 833 & 597 & 1,430 \\
\hline 2006 & 4,300 & 1,335 & 605 & 1,940 \\
\hline 2007 & 5,060 & 2,480 & 619 & 3,099 \\
\hline
\end{tabular}

Source: The number of membership is based on "Overview of corporate pension contract" Insurance Association and Trust Bank association etc. The number of plan is from Ministry of Health, Labour and Welfare 
Table.6 Trend of Defined Contribution Pension Plans

\begin{tabular}{|l|r|r|r|}
\hline \multicolumn{1}{|c|}{ Fiscal Year } & $\begin{array}{r}\text { Number of Plan } \\
\text { (Corporate type) }\end{array}$ & $\begin{array}{c}\text { Number of member } \\
\text { (Corporate type) } \\
\text { (10 thousand) }\end{array}$ & $\begin{array}{c}\text { Number of member } \\
\text { (Individual type) } \\
\text { (10 thousand) }\end{array}$ \\
\hline 2001 & 70 & 8.8 & 0.04 \\
\hline 2002 & 361 & 32.5 & 1.4 \\
\hline 2003 & 845 & 70.8 & 2.8 \\
\hline 2004 & 1,402 & 125.5 & 4.6 \\
\hline 2005 & 1,866 & 173.3 & 6.3 \\
\hline 2006 & 2,313 & 218.7 & 8.0 \\
\hline 2007 & 2,710 & 271.1 & 9.3 \\
\hline Source: Ministry of Health, Labour and Welfare, Japan & & \\
\hline
\end{tabular}

TQPP is approaching the final stages of abolition, and will reach a conclusion in less than three years. Thus far, a quarter of TQPPs that has already been transformed into another form has been converted to a corporate pension (EPF, DB Pension and DC pension).

\section{Policy actions towards the current crisis}

As a result of several reform measures taken under economic upheaval in the 1990s and the beginning of this century, the Japanese corporate pension system diversified, making it possible for employers to select an appropriate system according to their own characteristics. Consequently, employers are able to overcome the current economic crisis, to a certain extent, by using flexible regulations.

The Japanese government is convinced that, for example, Defined-Benefit type corporate pensions can operate stably by managing assets with a long-term perspective with periodical actuarial valuations, even though they tend to be temporarily affected by financial crisis given that they are pre-funded system and exposed to financial market risks.

However, as the funding regulations based on the plan termination liabilities require immediate additional contributions to recover under-funding on the part of the sponsoring companies, it sometimes places sponsor companies under too much pressure and threatens the continuation of the pension plans, especially when the economy is stagnant. In order to avoid such occurrences, the Government took the following series of special temporary measures.

\section{August 2002}

\section{Moratorium of contribution increase}

The Government allowed EPFs to postpone the necessary contribution increase, based on the FY 2001 actuarial valuations by one year, from April 2003 to April 2004, if the actuarial valuation shows that raising the contribution rate is necessary, even following the relaxed 2001 funding regulations. 
May 2003

\section{Moratorium of contribution increase}

The Government allowed EPFs to postpone the necessary contribution increase based on the FY 2002 actuarial valuations by one year, from April 2004 to April 2005 if the actuarial valuation shows that raising the contribution rate is necessary, even following the relaxed 2001 and 2002 funding regulations. (However, this only applies to pension funds that decided upon the benefit cuts at the General Assembly of the Council.)

\section{August 2008}

\section{Moratorium of contribution increase}

The Government allowed EPFs to postpone the necessary contribution increase, based on the FY 2007 actuarial valuations by one year from April 2009 to April 2010. (However, this only applies to pension funds that changed the contribution rate provision in the plan statutes based on the 2007 actuarial valuations.)

$80 \%$ of the existing EPFs are multi-employer type funds established by a group of small and mediumsized companies, and they are expected to face even more severe financial challenges in FY 2008 due to the recent adverse financial market. Given the severe circumstances, the Government announced a moratorium of additional contribution to cover under-funding as part of its 'Measures Against the Economic Crisis' on the 10th April 2009. The Government is determined to take action as soon as it is informed of the financial situation of corporate pension plans at the end of March 2009. 
Many EPFs and other corporate pension plans should evaluate their own funding level on a yearly basis following the end of each financial year to ensure sound and stable financial management and to secure the rights of beneficiaries and participants. In other words, they should evaluate their assets vis-à-vis their liabilities, and if the assets are lower than required, they should take the necessary steps, such as increasing contributions.

When under-funding occurs, it is usually necessary to raise contributions by the April of the year after the next in order to recover the fund, but the Government will allow a moratorium on contribution increase or other measures due to the current economic crisis.

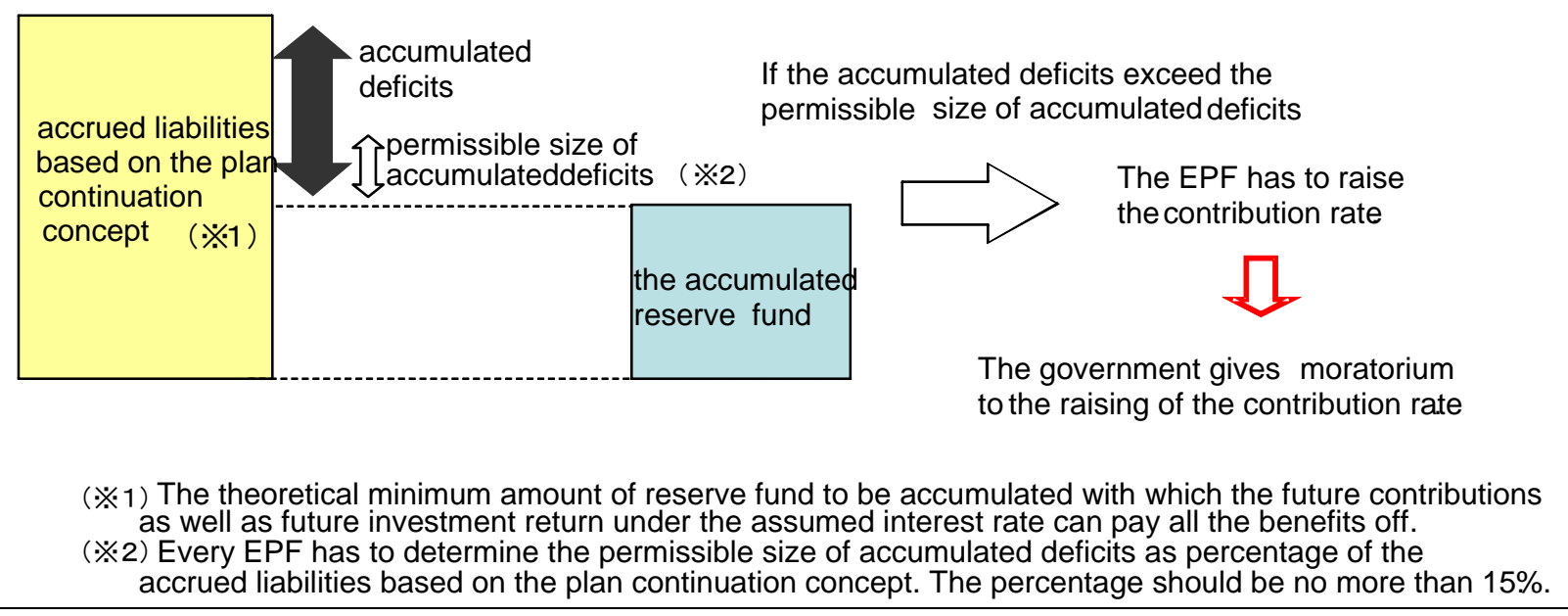

Table.7 Number of EPF plans and membership by types of establishment (End of March 2006)

\begin{tabular}{|c|c|c|c|c|c|}
\hline \multirow{2}{*}{} & \multicolumn{2}{|c|}{ Number of funds } & \multirow{2}{*}{$\begin{array}{c}\text { Membership } \\
\text { (thousands) }\end{array}$} & $\begin{array}{c}\text { Number of } \\
\text { enterprises }\end{array}$ & Membership per enterprise \\
\cline { 3 - 5 } & & $(\%)$ & 203 & 551 & 369 \\
\hline Single sponsor & 65 & 9.9 & 568 & 1,848 & 307 \\
\hline Allied sponsor & 78 & 11.9 & 4,451 & 123,644 & 36 \\
\hline Multiple-sponsors & 515 & 78.3 & 5,221 & 126,043 & 41 \\
\hline \multicolumn{2}{r}{ Total } & 658 & 100.0 &
\end{tabular}

\section{Conclusion}

In Japan the social security pension schemes provides coverage for all, irrespective of occupation and income, and so far adequate benefits have been provided through social security pension schemes. Corporate pension plans in Japan, therefore, provide additional benefits to the diversified financial needs in retirement and play a key role in enriching life after retirement.

In Japan, post-WWII corporate pension plans were first introduced in 1969 as Tax Qualified Pension Plans (TQPP) to level off the cost for severance payments or lump-sum retirement benefits. As a natural consequence, most corporate pension plans, even non-TQPPs, are conversions from the severance pay plans, which means that corporate pension plans have close links with the severance pay plans in most cases. Another characteristic of corporate pension plans in Japan is that, mainly because of the high respect that employers and employees have for the agreement between employers and employees, the majority of corporate pension plans are defined-benefit plans. As a result, a great amount of attention is paid to benefit 
rights. Nevertheless, in order to avoid a situation where pension plans are discontinued because of too much emphasis on benefit rights, we introduced a measure under the stagnant economy during the 1990s to allow pension plans to reduce accrued benefits only when the government acknowledge that the sponsoring companies will go bankrupt if employers are forced to continue to contribute to the pension plans to the same extent. At the same, time, we introduced another measure allowing pension plans to use smoothing for valuing its assets in order to avoid temporary market fluctuations. Thus corporate pension plans are given a framework in which they can manage themselves with a long-term perspective and adopt a flexible plan design, whilst still ensuring benefit rights.

As a change in accounting standard on retirement benefit in 1990s was one of triggers for prompting pension plans to return the substitution portion of the public pension, there are several criticisms of the accounting standard on retirement benefit in relation to private pensions. In order to produce effective measures which strengthen defined benefit pension plans, people concerned should carefully decide the accounting standards that would be best suited to the private pension system.

Japanese corporate pension plans rooted in a social context that is different from other countries, but the Japanese government believes that the balance between respecting benefit rights and providing a flexible framework for plan design is essential for the spread and sustainability of corporate pension plans. 